\title{
MORPHOGENETICAL KARST TYPES OF THE TRANSYLVANIAN MOUNTAINS (MT. APUSENI)
}

\section{MORFOGENETSKI TIPI KRASA V TRANSILVANSKEM GOROVJU (APUSENI)}

JÁNOS MÓGA ${ }^{1}$

${ }^{1}$ Eötvös Loránd University (ELTE TFK), Geography Department, 1117 BUDAPEST, Pázmány P. sétány 1/c HUNGARY, e-mail.Jmoga@freemail.hu 


\section{János Móga: Morfogenetski tipi krasa v Transilvanskem gorovju (Apuseni)}

V vseh Karpatih so kraški pojavi najbolje razviti v Transilvanskem gorovju (Apusenih), med Transilvansko kotlino in Veliko madžarsko ravnino. Ti pojavi so skladni z različno sestavo in različno kamninsko zgradbo ozemlja ter z različno naravo denudacijskih procesov. Avtor podaja pregled in morfogenetsko sistemizacijo tega najbolj zanimivega kraškega ozemlja.

Ključne besede: kraška morfologija, tipi krasa, Karpatski lok, Transilvansko gorovje (Apuseni).

\section{Abstract}

UDC: $551.44(234.421 .2)$

\section{János Móga: Morphogenetical karst types of the Transylvanian mountains (Mt. Apuseni)}

The most well developed karstic forms in the whole of the Carpathians emerged in the Transylvanian Mountains (Mt. Apuseni) situated between the Transylvanian basin and the Great Hungarian Plain. This phenomena correlates with the diversity of structure and rock formation, and to the multifold nature of denudation processes. My intention is to present a survey and morphogenetic systematization of the most interesting karstic regions.

Key words: karstmorphology, karst types, Carpathian range, Transylvanian Mountains (Mt. Apuseni). 


\section{INTRODUCTION}

The karst territories of the Carpathians and the mountains of the Carpathian basin are more or less well identified by karst researchers due to geological and geomorphological studies dating back for more then a century. The varied morphology of the regions with differentiated development history appearing in different geological structures gave an urge to the researchers to classify them into a number of morphological groups and to systematise the karst according to certain characteristics. The Carpathian ranges and the mountains of the Carpathian basin are situated in a number of countries, so the attempts for classification and typifying encountered the use of different methods in the neighbouring lands, based on different principles rising from regional particularities (Jakucs 1971, 1977, Hevesi 1986, Jakál 1978, 1993, Cocean 1985). In this study my aim is to integrate the traditions of the various karstological schools on a sample territory (the Transylvanian Middle mountains), where the large number and diversity of karst regions enables classification from different points of view (Table 1.). At the same time my intention is to show the most interesting karst regions of the Transylvanian Middle mountains.

\section{MORPHOGENETICAL KARST TYPES OF THE TRANSYLVANIAN MOUNTAINS (MT. APUSENI)}

The most well developed karstic forms in the whole of the Carpathians emerged in the Transylvanian Mountains (Mt. Apuseni) situated between the Transylvanian basin and the Great Hungarian Plain (Fig. 1). This phenomena correlates with the diversity of structure and rock formation, and to the multifold nature of denudation processes. Karstified rocks occur in the Transylvanian Mountains on such a large territory and in such a great variety that to show all is impossible in the scope of this paper. My intention is to present a survey and morphogenetic systematization of the most interesting karstic regions (karst plateaus of Padis, Padurea Craiului [Királyerdő] ${ }^{1}$, Scărişoara [Aranyosfői], Codru-Moma [Béli], Trascău [Torockói] Mountains, Transylvanian Ore Mountains (Munții Metalliferi).

\section{Paleokarst}

The levelled surfaces and karstoplains developing in the different periods of earth-history prove that favourable conditions for karstification were present in the earlier periods, mainly during the Mesozoic. Traces of older paleokarst remains were excavated on the dividing line of the Jurassic-Cretaceous by a number of researchers (Cociuba-Silvestru 1989, Patrulius 1976) on the karst regions of the Transylvanian Middle Mts., mainly on the territory of the Padurea Craiului Codru-Moma Mts., developing under a different climatic situation than at present (Fig. 2).

\footnotetext{
${ }^{1}$ Beside the official Rumanian place names at their first reference I provide the Hungarian version in paranthesis as well so the karstic objects can be identified in the territory inhabited by the Hungarian minority.
} 


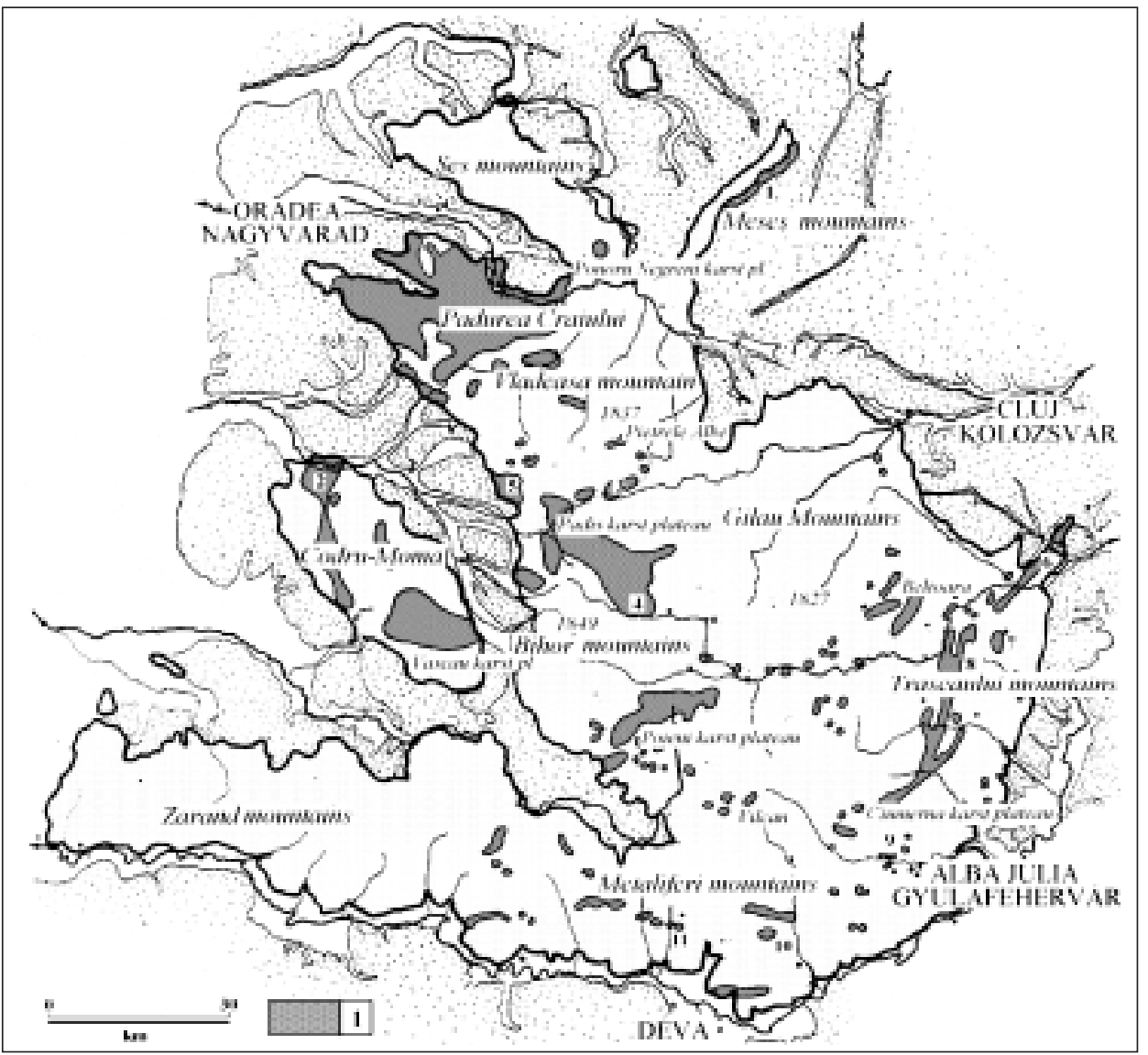

Fig. 1: Karsts of the Transylvanian Middle Mts. Legend: 1. karsts

1. Eocene Nummulite limestone karst of the Meseş Mts., 2. Dumbrăvița plateau, 3. Karst of the Someşul Cald source region, 4. Scărisoara karstplateau, 5. Karsts on the W edge of the Bihar Mts., 6. Turda limestone plateau, 7. Piatra Secuiului [Székely-kö], 8. Bedeleu plateau, 9. Olistolits of the Trăscăului Mts., 10. Pleșa Ardeului karstplateau, 11. Măgura Băiței karst plateau.

\section{Levelled surfices of the limestone plateaus (karstoplains)}

The development of the nappe structure of the Transylvanian Mountains ended essentially during the nappe formation of the Upper Cretaceous period. In the later periods, only uplift and sinking of the area took place, accompanied by important levelling processes. In the last decades, Romanian geomorphologists described three such planated surface remnants, formed via levelling (Pop 1962). These can be found at different heights, due to tectonic movements. The strik- 


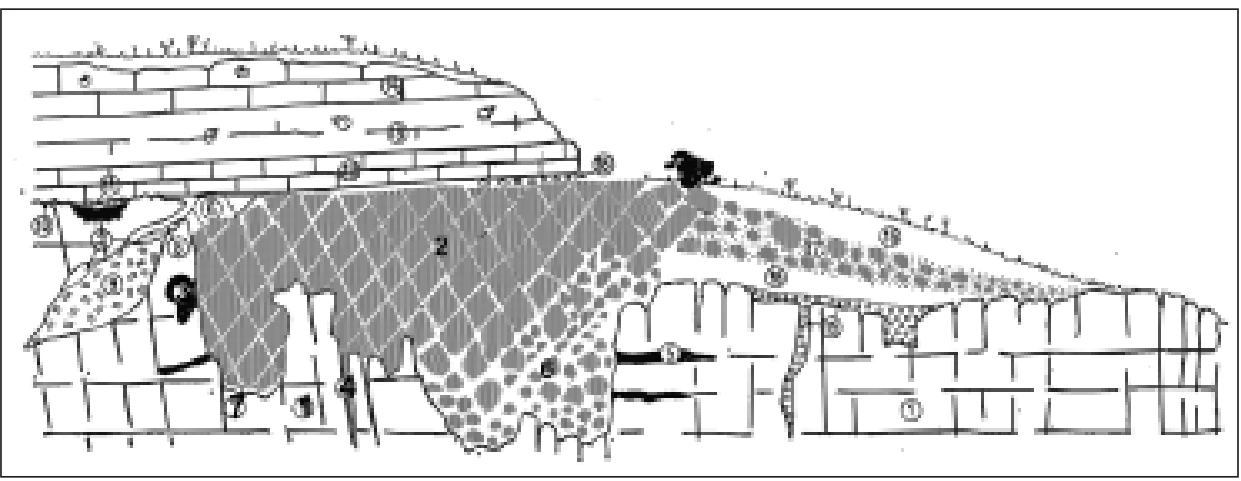

Fig. 2: Paleokarst in the Padurea Craiului Mountains (after D. Patrulius).

Legend: 1. Tithonian limestones, 2. Red ooidal bauxite, 3. Karst pocket filled with bauxite, 4. cracks filled with bauxite, 5. Paleokarst cavity (Jurassic), 6. Ooidal bauxite, 7. Caoline like bauxite, originated from the red bauxite, 8. Marls, 9. Cristallized kalcit, 10. Microkarst (on the boundary of Jurassic-Cretaceous), 11. Jurassic limestone breccia, 12. Black limestone (Characeae), 13. Massive grey limestone, 14. Grey (Pachiodontal) limestone, 15. Young gravel in the faults of the Jurassic limestone, 16. Yellow clay, 17. Bauxite gravel in clay, 18. Yellow clay filled with the gravels of the Cretaceous limestone cemented with bauxite and Characeae limestone.

ingly flat peaks rising highest in the Transylvanian Mountains were formed by tropical surface planation taking place in the Cretaceous and the end of the Oligocene. The peaks of the Gilau and Bihor Mountains and Vlădeasa, rising between 1600-1800 m, are assumed to be the remnants of tropical peneplain surfaces (Fărcaş-Cîrligațele surfaces). The 1000-1400 m high surfaces embracing the three highest mountains developed by a levelling process taking place under Mediterranean weather conditions in the Miocene epoch (Măguri-Mărişel surfaces). Lastly, the researchers identified a third, lower pediment surface as well, formed in the Pliocene (Feneş-Deva surfaces). These three surfaces form a step-like relief in the Transylvanian Mountains. The differently aged and structured limestones also appear ordered to the above mentioned geomorphological levels. Similar levelled surfaces, karstoplains were mentioned by Rumanian karst morphologists from the territory of the Transylvanian Middle Mts. (Cocean 1985). The highest plateaus of the Trascău Mts. (Ciumerna and Bedeleu plateaus), the Poieni karst plateau in the Ore Mts., as well as the Scărişoara and the Padis plateaus in the Bihar Mts. were identified with the Fărcaş-Cîrligațele surface. These plateaus were situated between 1200-1400 m and are mentioned as the CiumernaScărişoara karstoplain. The Vaşcău-Zece Hotare karstoplain, corresponding with the Măguri-Mărişel surfaces is the most widespread in the territory of the Transylvanian Middle Mounts. With a number of smaller karst plateaus, the larger, 600-800 m high plateaus of the Codru-Moma and Padurea Craiului Mts., rich in surface and subsurface karstic forms, belong to this group. The youngest and lowest (400-500 m) Dumbrăvița karstoplain corresponds with the Feneş-Deva surfaces. The low plateaus of the northern edge of the Padurea Craiului Mts., and the Dumbrăvița plateau of the northern border of the Codru Moma Mts. belong to this group. 
Table 1.

1. Morphogenetic karst types

1.1. paleokarst

1.2. levelled surfices of the limestone plateaus (karstoplains)

1.2.1. Ciumerna-Scărişoara karstoplain (Danian-Oligocen)

1.2.2. Vașcău-Zece Hotare karstoplain (Miocen)

1.2.3. Dumbrăvița karstoplain (Pliocen)

2. Geological-structural and lithological conditions of the karst

2.1. old crystallin limestone blocks of the core mountains

2.2. mantle series of the Bihar autochthonous core mountains

2.2.1. monoclinal crest and ridges

2.2.2. synclinals

2.3. Nappe structures of the Transylvanian Mountains

2.3.1. nappes formed out of Mesozoic limestones

2.3.2. smaller-sized klippe

2.3.3. olistoliths

2.3.4. patch reef

2.4. Tertiary basin sediment (Eocene-Oligocene limestones)

3. Types of karst relief:

3.1. mountain karst

3.1.1. plateau karst

3.1.2. dissected karst of horst and combined fold-fault structures

3.1.3. karst of klippen structure

3.2. karst of pediment plains and terraces

3.3. basin karst

3.4. high mountain karst

4. Morphoclimatic karst types:

4.1. karst of the temperate zone (moderately continental, moderately warm and moderately humid climate, annual precipitation total is $600-1700 \mathrm{~mm}$ ).

4.2. high mountain climate karst

\section{GEOLOGICAL-STRUCTURAL AND LITHOLOGICAL CONDITIONS OF THE KARST}

\section{Old crystalline limestones blocks of the core mountains}

The karstic surface forms were developed on limestones of different age and character. The oldest karstifiable rocks are the crystalline limestone and marbles from the Palaeozoic, which took part in the building of the Bihar autochton and the Bihar nappe. The Gilau Mts. rising on the eastern edge of the Transylvanian Middle Mts. are mainly built from Precambrian metamorphic blocks (slate) of the Bihar autochton and the penetrating Caledonian granite. Karstic surface forms were formed only on the southern edge of the mountain, situated in the Palaeozoic crystal- 
line limestone running in a narrow band. The crystalline limestone band crossing the water catchment area is broken through by narrow and deep passes (Cheile Runcului, Ch. Poşaga) of the waterflows starting from the watershed of the Gilau Mts. and continuing towards the Arieş valley. The most interesting part of the karst range, according to landscape as well, is the $600 \mathrm{~m}$ rockface of the Belioara-Scărița $(1382 \mathrm{~m})$ breaking into the valley head of the Poşaga valley. The rock castle incorporated mildly in the sub-mountain peaks of the Gilau Mts. is one of the most spectacular creation of nature. In its giant cliff, which is dissected into soaring towers, dry valleys, and gorges, a giant hollow, the gate of Belioara, an enormous, open roofed collapsed cave is found, which once was engraved by the flowing waters into the hard rocks.

The biggest karst plateau of the Ore (Metaliferi) Mts., the Poieni plateau is also situated in crystalline limestone. It rises with a steep rock wall from the Arieş Mic valley between Sohodol and Avram Ianku villages. There are karren fields on the $1300 \mathrm{~m}$ high summits of the Poieni plateau, some $60 \mathrm{~km}^{2}$ in area. There is a conspicuously small number of dolines on the surface of the hardly dissolvable crystalline limestone, and the debris covering the surface is high enough for agriculture. The water infiltrating on the plateau surfaces in the karst springs of Arieş Mic and Crişul Alb. The most widespread are the Mesozoic carbonated rocks of the Transylvanian Middle Mts; they partly built up the mantle series of the Bihar autochtonous core mountains and partly form the nappe structures of the Transylvanian Mts. The karst regions of the Bihar Mts, the Padurea Craiului, the Codru-Moma, and the Şes Mts. also belong here.

\section{Mantle series of the Bihar autochthonous core mountains}

The most developed and varied karst regions of the Transylvanian Middle Mts. are found in the Bihar Mts. Besides the Padis plateau, the Scărisoara karst plateau and the karst of the Someşul Cald source region, which are well known, lesser studied and smaller karst territories are also found here (karst along the Crişul Băița stream, karst territorries around Fericel and Sighiştel villages and Tătăroaia Mt. 1291 m) (Móga 1995). These draw attention to themselves with their diverse surface and subsurface karst phenomena. A large part of the carbonated rocks of the Bihar Mts. belongs to the Bihar autochton. This tectonical unit surfaces from under the nappe on the NE part of the Mts. The karstified Mesozoic limestone appears in NW-SE zones between the Bulz and Valea Rea stream and the Arieş valley. The carbonated rocks resting on crystalline slates of the autochton, on Permian sandstone and on Lower Triassic fragmented sedimentary rocks form a monoclinal structure slanting towards the SW with a total thickness of $1200 \mathrm{~m}$. At the bottom of the sediment section Lower Triassic limestone and dolomites are found, followed by non-karstified, Lower Jurassic debris (Ianovici et al. 1976). On its top Middle-, and Upper- Jurassic and LowerCretaceous limestone was placed which also played an important part in the formation of karstic surface forms.

\section{Monoclinal crest and ridges}

At the northern part of the Bihar Mts, between the spring branches of the Crişul Negru, Someşul Cald and Arieş lies the Padis plateau, showing the most interesting karstic surface forms of the Transylvanian Middle Mts. (Fig. 3). The 1200-1400 m high plateau, in comparison with the peaks rising on its border (Magura Vănătă 1641 m, Biserica Moțului 1466 m, Glăvoi 1426 m, 


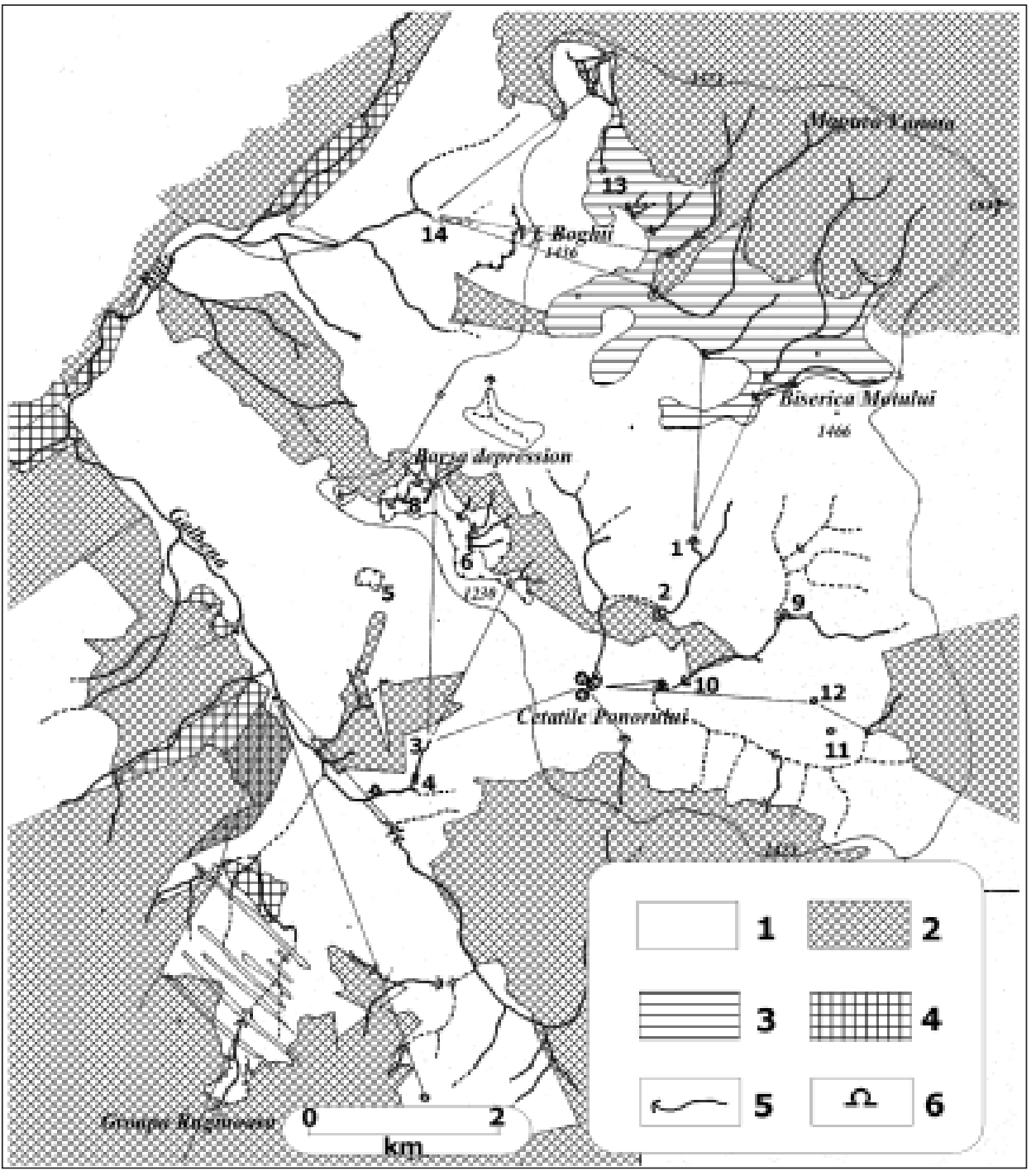

Fig. 3: Caves and swallow holes of the Padis karst plateau (after Orăşeanu J. 1991)

Legend: 1. Limestone, 2. Sandstones, conglomerates and shales (Permian, Lower Triassic, Jurassic), 3. Gravel, clay and sand, 4. Banatit (granitoid rocks) (Cretaceous-Paleocene).

Karst Objects: 1. Ponor karstspring, 2. Poiana ponor, 3. Galbena karst spring, 4. Galbena spring cave and waterfall, 5. Focul Viu (Eszkimó) cave, 6. Black cave, 7. Barsa ice cave, 8. Zăpodie ice cave, 9. Ursului karst spring, 10. Căput cave, 11. Av. Negru shaft, 12. Av. Gemănata shaft, 13. Vărăşoaia lake, 14. Boga karst spring. 
Borțigului 1342 m, Piatra Galbenei 1234 m, Bălileasa 1267 m, Boghii 1436 m and Vărăsoaia $1462 \mathrm{~m}$ ), is situated basin-like with an endorheic $37 \mathrm{~km}^{2}$ territory at its centre, which is connected to the neighbouring water systems through underground streams. All waterflows, which start from the peaks surrounding the plateau, run towards the karstic drain and disappear in swallow holes to surface at a lower section of the valley, or in a karst spring at the foot of the plateau.

On the karst plateau the sequence of karstified and non-karstified rocks formed a variable water system of surface and sub-surface waterflows. The Lower Triassic fragmented sedimentary rocks (at the environment of Magura Vănătă), the Lower Jurassic impermeable rocks (the section between the Plai valley-Barsa trench-Ursului spring valley), as well as the Permian layers (territory between Mt Borțigului and Mt. Glăvoi) formed a favourable situation for the development of surface waterflows (Veress 1992). Streams originating on top of the upper impermeable sediments, reaching the limestone border after a short surface period, are baticaptured, and their waters following the bend of the monoclynal structure flow from $\mathrm{E}$ to $\mathrm{W}$ and feed the Crişul Negru.

The waters disappearing in the swallow holes of the Vărăsoaia depression, at the NE edge of the Padis plateau, together with the waters of swallow holes opening at the foot of the Magura Vănătă, feed the abundant Boga spring issuing from under the northern rockface. According to water tracing, here an enormous - today still unknown - cave system is hidden. The fall of the underground stream between the Vărăsoaia ponor and the Boga spring is $615 \mathrm{~m}$, which is the second largest level difference shown by water tracing method in the Bihar Mts (Orăşeanu et al. 1991).

The waters of the other swallow holes at the foot of Magura Vănătă appear in the Ponor spring issuing at the edge of Poiana ponor. The spring bursting forth from the mouth of the spring cave flows through the bottom of the depression and after about a $\mathrm{km}$ disappears once again in the Poiana ponor swallow hole. At the period of snow melt following a fast warming up and after rainfalls such a large quantity of water is collected at the bottom of the depression that the swallow hole is unable to absorb it and a lake develops. The waters flowing into the Poiana ponor swallow hole surface at the entrance of the Cetățile Ponorului [Csodavár] and are united with the Castle stream and flow in the main branch of the cave, appearing in the Galbenă spring. The Cetățile Ponorului is the most spectacular karstic phenomena of the Padis plateau as well as the Carpathian Mts., comprising two enormous collapsed dolines (Castle Courts) and a $70 \mathrm{~m}$ large cave entrance with a gigantic cave branch. The Cetățile Ponorului is the deepest point (almost $1000 \mathrm{~m}$ ) of the Padis plateau, the collecting point of surface and sub-surface waters, and the most important intermediate station of the Crişul Pietros underground stream system.

The south-eastern part of the Padis plateau is dissected by valleys and is difficult to approach. Between the Seacă (Dry) valley and the Ursului spring's valley depression, we can find permanent waterflow only in the latter, which is fed by the Ursului and Rece (Cold) springs. The waters of the two springs, after meeting, disappear in the swallow hole of the Câput cave and flow towards the entrance hall of the Cetățile Ponorului in the underground corridor of the cave. The active waterflow of the Seacă valley running in the deep was found during the research of the deep shafts (Avenul Negru, Av. Gemânata) opening on the territory of the Lumea Pierdută. The water disappearing on the border of the Lower Jurassic sandstone and limestone of one of the northern branches of the dry valley was coloured and the traced water appeared first in the stream of the Gemânata shaft, then in the abundant spring of the entrance gallery of Cetățile Ponorului (Orăşeanu et al. 1991). 
North from the Cetățile Ponorului the biggest closed karst valley of the Padis plateau, the Barsa depression, opens, developed at the border of karstified and non- karstified rocks (Fig. 3). The area of the Barsa depression is $2,5 \mathrm{~km}^{2}$, its lowest part is at $1018 \mathrm{~m}$, while its edge is $1270 \mathrm{~m}$ high. From the northern and eastern borders of the endorheic basin built up from Lower Jurassic impermeable rocks, a number of small waterflows issue, which at the bottom of the depression disappear in swallow holes. With the opening of these swallow holes explorers excavated a number of giant cave systems with a length of $15 \mathrm{~km}$. From a long time on the Gheț. Zâpodie ice cave, situated in the north-western part of the depression, was known. According to Schmidl, an Austrian geologist in 1863, ice was mined from the cave for the needs of the confectioner of Belényes (today Beiuş). The sub-surface branches of the Zâpodie ice-cave are in connection with Black cave $(10879 \mathrm{~m})$ opening nearby to the Tăul Negru lake. In a swallow hole developed on the same rock boundary is the second longest cave of the Barsa depression, the Gheț. de la Barsa. Its entrance section was explored and arranged for tourists at the turn of the XIX-XX. century by Gyula Czárán, the most self-sacrificing researcher of the Bihar Mts. Out of the number of lesser caves and shafts of the Barsa depression the Peşt. Ştevia Lupii is well known - its water was coloured and it appeared in the Galbenă spring. It was also in the Galbenă spring that the tracing material from the underground stream of the Barsa ice-cave reappeared, which proved that the swallow holes of the Barsa depression conduct their waters towards the Galbenă spring (Orăşeanu et al. 1991). The Galbenă spring collects the waters from the largest part of the Padis plateau. The Galbenă stream, starting from the spring-lake in a picturesque valley forced into narrow rock walls, once again disappears, only to emerge in a huge waterfall issuing from the Galbenă spring cave a bit lower. From then on it flows on the surface towards the Crişul Negru.

One of the most well-known caves of the Padis plateau, the (Peşt. Focul Viu [Eszkimójégbarlang]) opens on the western edge of the Barsa depression, where the fantastic ice formations were formed in an enormous hall filled with ice generated from the snow and ice masses flowing in from above. The ice formations show an unrivalled sight in the summer with the breaking up of the cave's ceiling, in the light of the infiltrating sun.

On the south-eastern part of the limestone band comprising the Padis plateau, the Scărisoara plateau is situated, rising between the Gîrda Seacă and the Ordîncuşa valleys. With its interesting karst phenomena, it belongs to one of the most attractive territories of the Bihar Mts. Situated between the two karst valleys, the $8 \mathrm{~km}^{2}$ plateau is poor in water, with its only waterflow, - the Ocoale stream - collecting its waters from the slate and sandstone zones surfacing in the heart of the plateau. After a short surface phase it disappears in the swallow hole opening at the rock boundary. Its dried out, shallow riverbed can be traced in the limestone surface, with a number of old and abandoned swallow holes, dolines, caves at its bottom. On the southern edge of this valley, a giant collapsed doline opens, hiding the Scărisoara ice cave.

In the entrance hall and in the galleries and halls opening from it about $75000 \mathrm{~m}^{3}$ ice is accumulated. The age of the ice is approximately 4000 years. The ice-cave belongs to the driedout, upper part section of the baticaptured Ocoale stream, the branches with active, permanent waterflows run deeper. The waters emerge in the lower section of the Gîrda Seacă valley.

At the southern edge of the plateau, at the bottom of a collapse doline, the Ghețarul Zgurăşti ice-cave opens, where in its entrance hall a temporary lake was formed (at high water level the surface of the lake exceeds $5000 \mathrm{~m}^{2}$ ). The waters of the lake flow towards the Ordîncuşa valley, and reach the surface in the stream of the enormous Poarta lui Ionel cave. 
Giant-sized caves open in the gorge cut in the western border of the plateau. In the upper section of the Gîrda Seacă valley, in the Gîrdişoara valley, the stream coming from Bătrîna disappears a number of times, forming a cave system about $5 \mathrm{~km}$ long (Coiba Mare). At the bottom of the cave system incorporating gigantic galleries and halls, a number of underground streams are united producing lakes, waterfalls and siphons. The underground stream surfaces in the Teuz spring. Near the Coiba Mare cave, in the slope above the valley bottom, the third ice-cave of the karst region, the Gh.Vărtop opens, which is under protection, due to its richness in dripstones.

In the structure of the Padurea Craiului Mts, rising between the Crişul Repede and Crişul Negru basins, the Mesozoic sediments play an important role. The major part of the Mts. belong to the Bihar autochton, covered by sedimental cover layers, while the lesser part is connected to the Codru nappe system. The Mesozoic sediments, covering $83 \%$ of its area, were developed in three big sedimentation cycles, starting with continental and shallow sea episodes, continuing or ending in carbonate rock deposits in reef and Laguna environment. The sediments formed in specific earth-historical periods show a somewhat regular arrangement, they appear in NE-SW rows. The line of Triassic rocks follows the Jad valley, while to its west the Jurassic rocks appear, whereas the north-western third of the mountain is built up of rocks from the Cretaceous period. In all the three cycles karstified rocks were developed in abundance, forming $40 \%$ of the mountain (Ianovici et al. 1976.). The varied tectonical arrangement of karstified and non-karstified rocks, and its mosaic-like positioning is reflected mainly in surface forms and in the development of a river network.

The Padurea Craiului Mts. belongs to the lower members of the Transylvanian Middle Mts., its highest peaks surpass $1000 \mathrm{~m}$ only by little (Hodringuşa $1027 \mathrm{~m}$ ), whereas the peaks and planinas in the centre of the mountain reach only a height of 600-800 m. Towards the north-west the height of tops decreases, while at the edges we can find $400 \mathrm{~m}$ low plateaus, but with the steep, barren, karred slopes developing along fractures, even these are sharply separated from the surrounding Neogenic basins.

A great variety of surface and sub-surface karst phenomena was formed on the planinas of different heights (Rusu 1988). The dolines, series of dolines, uvalas, karst basins, ponors, gorges and dry valleys of different measurements and form dissect the surface. There is not such a great number of swallow holes, karst springs and caves in any of the other mountains of the Carpathians as in the Padurea Craiului. More than 60 underground streams were identified by to water tracing, and about 700 caves have been explored up to now, among them the longest cave system of the Carpathians, the $42 \mathrm{~km}$ long Peşt. Vîntului [Szelek barlangja] (The cave of Winds). Out of the numerous caves only two are open to public - the Peșt. Crişului [Zichy-barlang], whose stream after a short journey cascades down into the Crişul Repede in a waterfall from a self-made travertine hill, and the Peșt. Meziad. In 1956, in the Peșt. Ciur-Izbuc cave traces of Prehistoric men were found together with cave bear remains.

In the Padurea Craiului Mts. the surface water system is replaced on large areas by subsurface waterflows. With gradual baticapture the river system slowly disintegrates and is transferred into the depths. The closed karstified basins are tapped by underground rivers, which appear in abundant karst springs, spring caves (Peşt Bulz, Izbindis-spring, Peşt. Aştileu) in the edge of the mountain. Permanent waterflows are formed only on non-karstified rocks and regions with larger water collecting areas. These waterflows also disappear most often in swallow holes opening on the limestone boundary, or by cutting deep gorges they break through the zone of karstified 
rocks, until they reach neighbouring basins, but on their journey they lose a lot of water due to filtration. At the waterflows of Padurea Craiului the different degrees of drying out and baticapture can be observed.

\section{Synclinals}

The Ponoru Negreni karst of the Şes Mts. rising in the northern part of the Transylvanian Middle Mts. belongs to this type. The low fracture blocks of the Mts. is built up of Precambrian/Early Palaeozoic metamorphic rocks (micacshists, gneiss, amphibole); younger sediments only appear at a small spot at the south-eastern part of the Mts, at the Ponoru Negreni region. The planina, only $1-1,5 \mathrm{~km}^{2}$ in area was formed on Mesozoic limestone remnants, north-east from the Pasul Piatra Craiului (Ianovici et al. 1976). Into the shallow, plate-shaped synclinal of the Triassic layers rising to $750-800 \mathrm{~m}$ waters infiltrate and develop characteristic karst forms. The higher edges encircle the shallow, large central depression on all sides. Dolines, series of dolines and swallow holes are virtually only

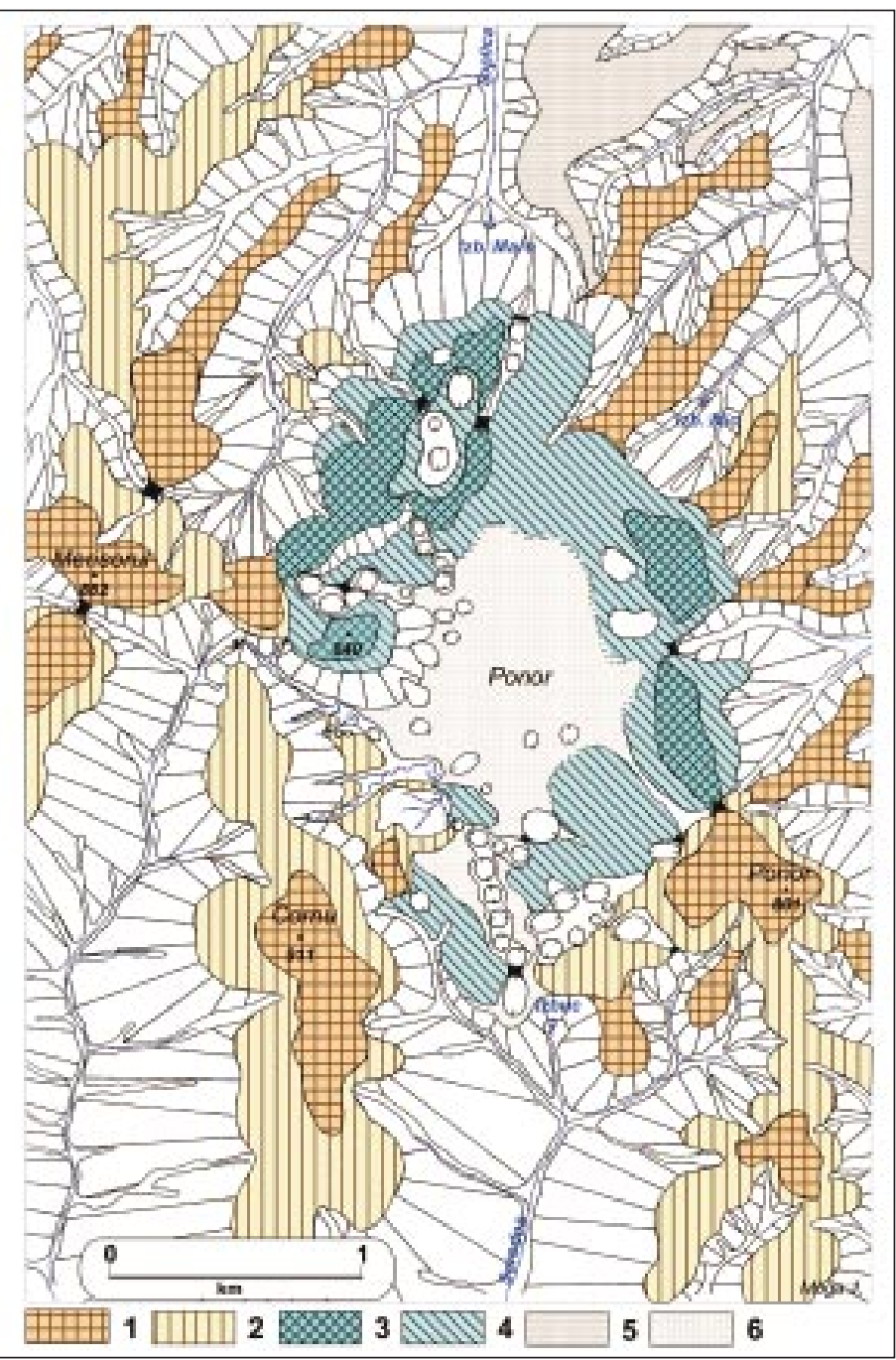

Fig. 4: Ponoru Negreni karst plateau Şes Mountains.

1. Summit of the intervalley back developed in non-karstic environment, 2. Intervalley back developed on non-karstic rocks, 3. Higher back of the karstic plateau or the summit of the intervalley back (on carstic rocks), 4. Karstic plateau or intervalley back developed on Karstic rocks, 5. Pannonian sediments, 6. Quaternary sediments. 


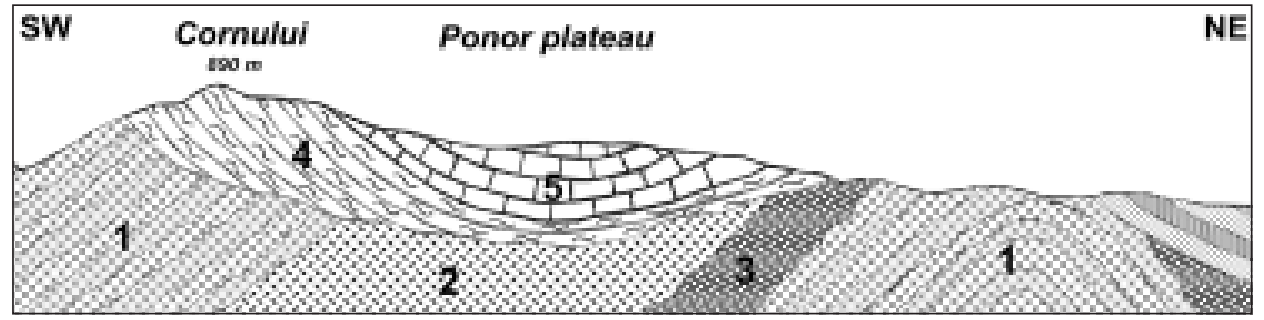

Fig. 5: Cross section of the Ponoru Negreni karst plateau Şes Mountains (synclinal type karst plateau) (after the 1:50 000 geological map of Romania, 28. Tusa). 1. Mica schists (Upper pcm.), 2. Mica schists (muskovit-biotitic), 3. Paragneisses (Upper pcm.), 4. Lower Triassic shales and sandstones, 5. Middle Triassic limestone.

found at the western edge of the plateau near to the rock boundary. The waterflows starting from the slopes of the Vrf. Merisorului $(882 \mathrm{~m})$ and Vrf. Cornului $(890 \mathrm{~m})$, both rising on the western side of the karst plateau built up of impermeable rocks, disappear in swallow holes forming on rock boundary (Figs. 4, 5). A few lesser caves were explored in the karst region as well (Tulogdi 1972). The oozing waters issue at the edge of the plateau, also on the rock boundary. The Bărcau [Berettyó] river rises from the two abundant karst springs (Izb. Mare and Mic) bursting forth on the northern edge of the plateau. In the vicinity of the larger spring the stream cascades from a travertine hill with a $10 \mathrm{~m}$ long fall. The karst spring that developed on the southern part of the plateau, at the valley head of the Seredos stream, is connected to the water system of the Crişul Repede. The watershed of the Crişul Repede and the Bărcau cuts through the Ponoru Negreni karstplateau.

\section{Nappe structures of the Transylvanian Mountains}

\section{Nappes formed out of Mesozoic limestones}

The Vascău karst plateau, rising at the southern part of the Codru Moma Mts. at an average of $600 \mathrm{~m}$, is built up from the Mesozoic carbonated rocks of the Codru nappe system. The wellkarstified Middle and Upper Triassic limestone occupy an area of $90 \mathrm{~km}^{2}$ at the spring region of the Crişul Negru and form a large, eastward bent monoclynal structure (Ianovici et al. 1976) and cover the non-karstified Perm and Lower Triassic rocks of the mountain (Fig. 6). The latter surface only on the high peaks framing the plateau (Moma $854 \mathrm{~m}$, Momuța $930 \mathrm{~m}$, Arsura $819 \mathrm{~m}$ ), which rise from the watershed of the karstic territory on the south and west.

The tops of the Vascău karst plateau, covered by dolines, was uplifted gradually from the surface of the Beiuş basin due to Tertiary and Quaternary structural movements. Its highest peaks form a NW-SE directed range. The greater part of the karst region of average height lies on the east side of this range, and at its western foot karst hollows (Ponoare-Pociovalişte, Arinda, Bănişoara, Ponoras, Recea) line up with the fusion of dolines, blind valleys and swallow holes developing along structural lines on rock boundaries. The most developed swallow holes of the Vascău karst plateau line along partly the above mentioned karst basins, and partly at the foot of 


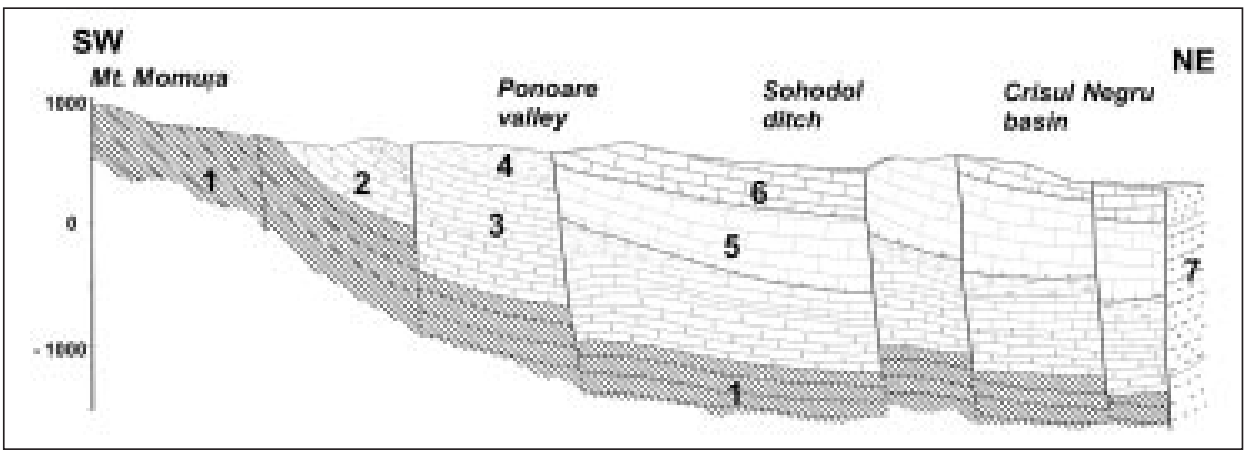

Fig. 6: Vaşcău plateau karst (Codru-Moma) Mountains (after I. Orăseanu).

Legend: Moma Nappe: 1. Lower Triassic shales and sandstones, 2. Middle Triassic black dolomites, 3. Middle-Upper Triassic grey limestones, 4. Upper Triassic limestones, Văşcau Nappe: 5. Middle Triassic Massive white limestones, Colești Nappe: 6. Upper Triassic grey reef limestones, 7. Permian Phylites with diabas tufas intercalations.

the watershed range, and convey the waters of the higher peaks of non-karstified rocks into the depths. The waterflows following the slope of the plateau, at an earlier phase crossed the plateau, but the majority of the water is swallowed now at the rock boundary. The dry valleys and doline lines continuing after the swallow holes reveal the route of earlier waterflows. Only the Tarina stream, issuing from the south-west part of the plateau, and the Ponor- és Pesterelii streams, starting from the Momuța slopes, have longer valleys. The permanent waterflow of the Tarina stream continues its many km long journey, cutting a deep valley into the limestone surface, until it reaches the Sohodol ditch, where it is swallowed. The water of the other two streams seeps away already at the edge of the plateau, and in their dry valleys fused together below, also opening into the Sohodol ditch, water flows at exceptionally big rainfalls and at snowmelt.

The fracture lines and tilt blocks running parallel to the Beiuss basin indicate the direction of the biggest dry valley, the so-called Sohodol ditch. The ditch-like depression, $6 \mathrm{~km}$ long and $0,5 \mathrm{~km}$ broad virtually dissects the karst plateau into two parts. The ditch is in fact the blind valley of the Tarina stream, which in the past conducted the waters of the plateau towards the Crişul Negru river on the surface. Permanent surface waterflow today is only found on the upper part of the Sohodol ditch falling towards Ponoarele village. The meandering waterflow at the bottom of the Sohodol ditch, at the middle part of the ditch, at the border of Izbuc, breaks into the deep shaft of the Cîmpenească cave, which is one of the most attractive and well-known karst phenomena of the Transylvanian Middle Mts. The underground stream disappearing at the Sohodol cavern breaks forth at the foot of the karst plateau, at the Vascău side as the Boiu spring. According to the evidence of water tracing, the water disappearing in the swallow holes of the Ponor and Pesterelii streams reappears here as well, so the greater part of the plateau belongs to the catchment area of the Crişul Negru.

The well-known Izb. de la Călugăra [Dagadó spring] issues on the southern edge of the Vascău karst plateau, but already in the catchment area of the Crişul Alb. The spring obtained its fame because of its unusual water eruptions. The waters of the spring surface through a siphon system. 


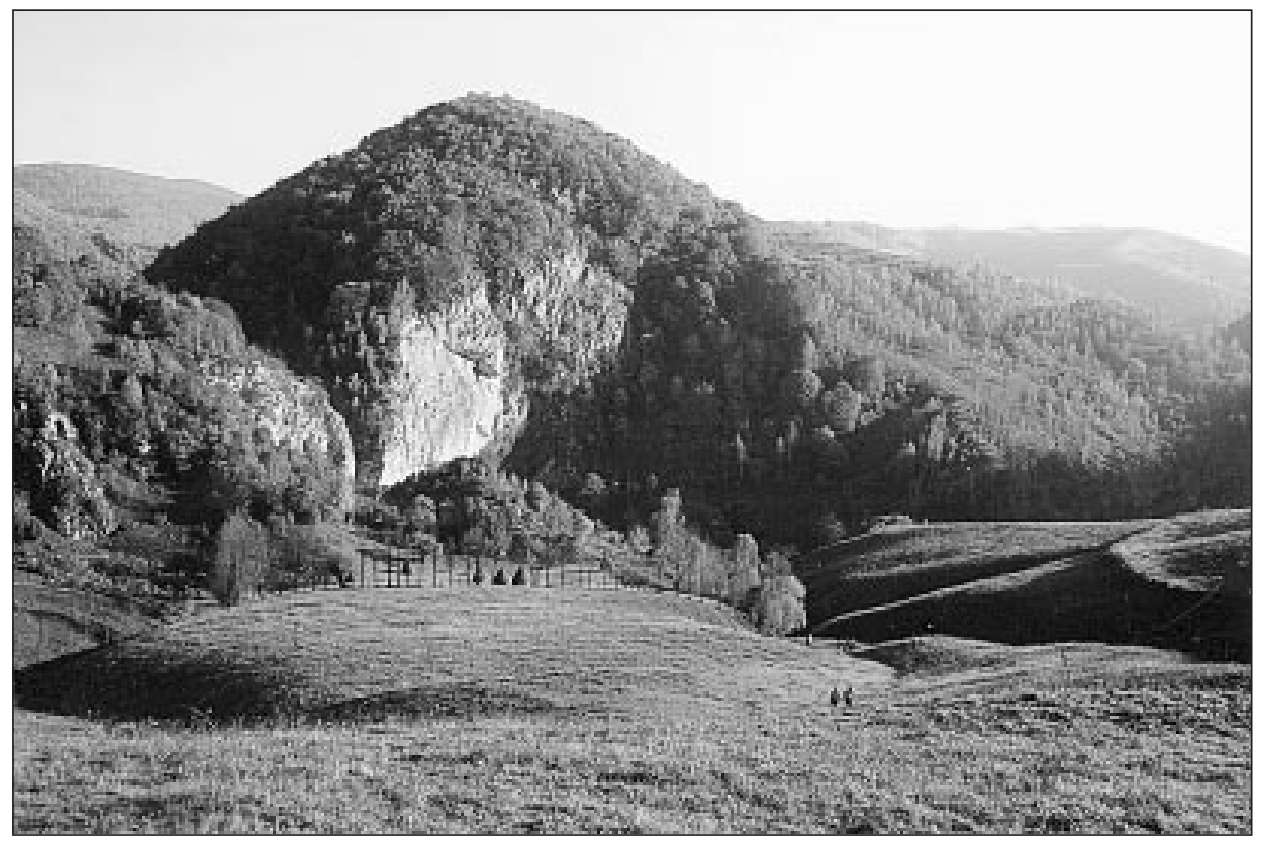

Photo 1: The picturesque Vînată swallow hole of the Huda lui Papară cave.

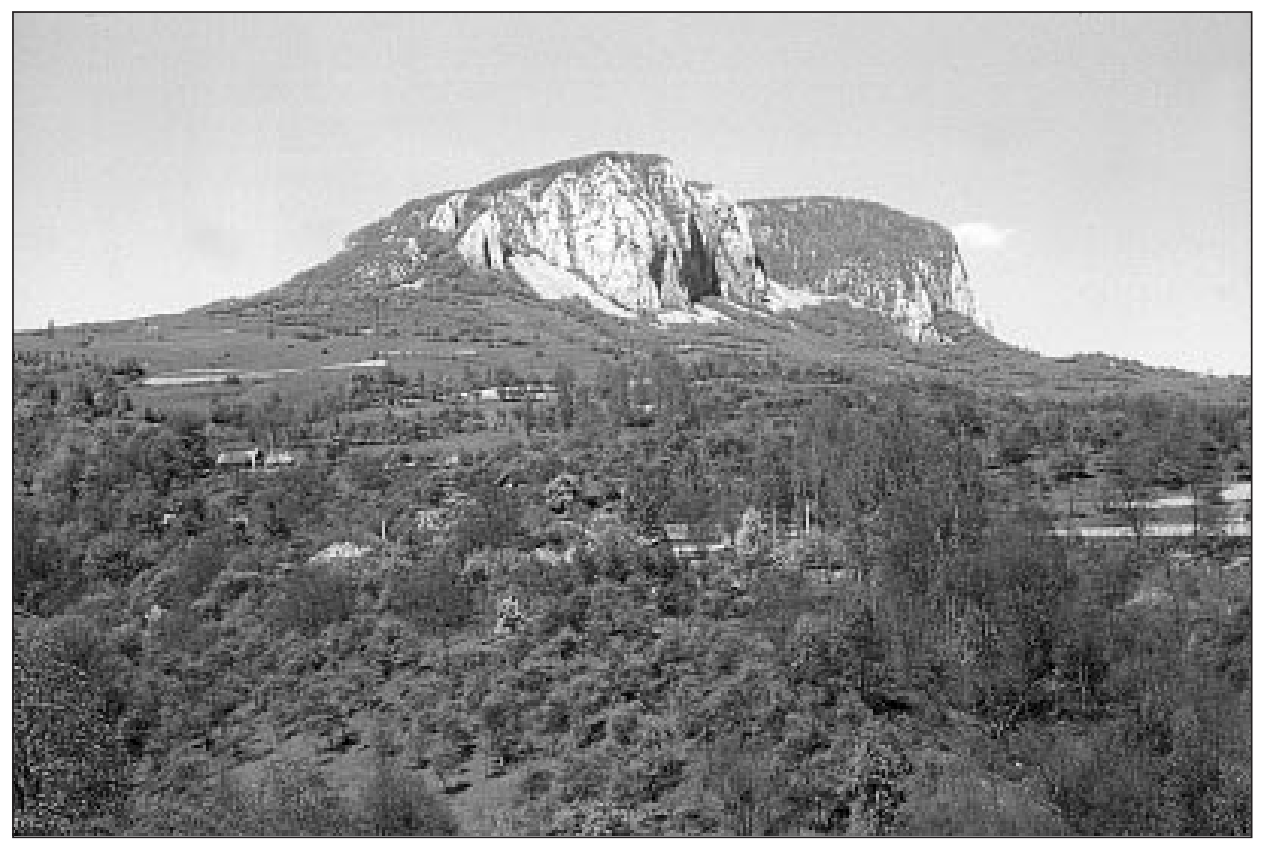

Photo 2: Smaller sized klippe (Vîlcan) 


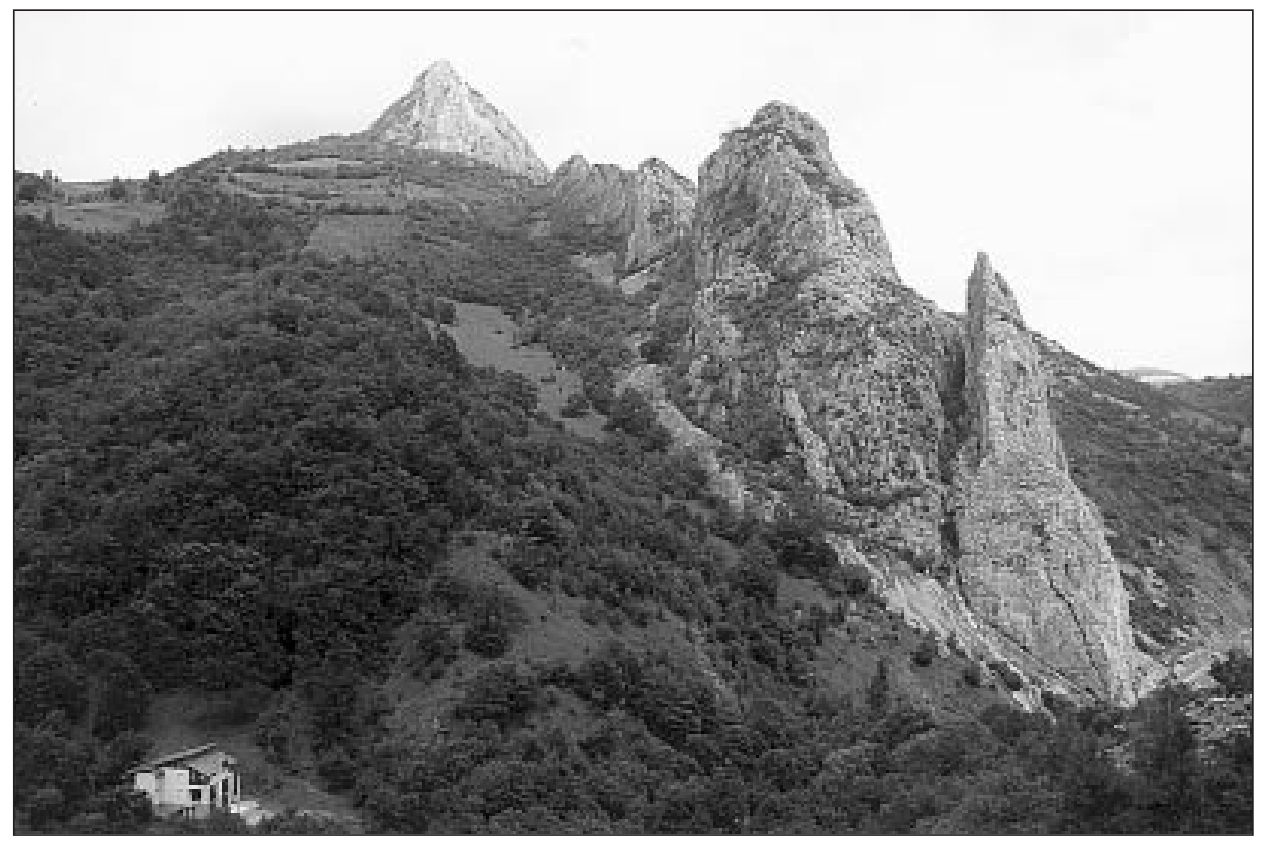

Photo 3: Smaller sized klippe (Vârful Plesii).

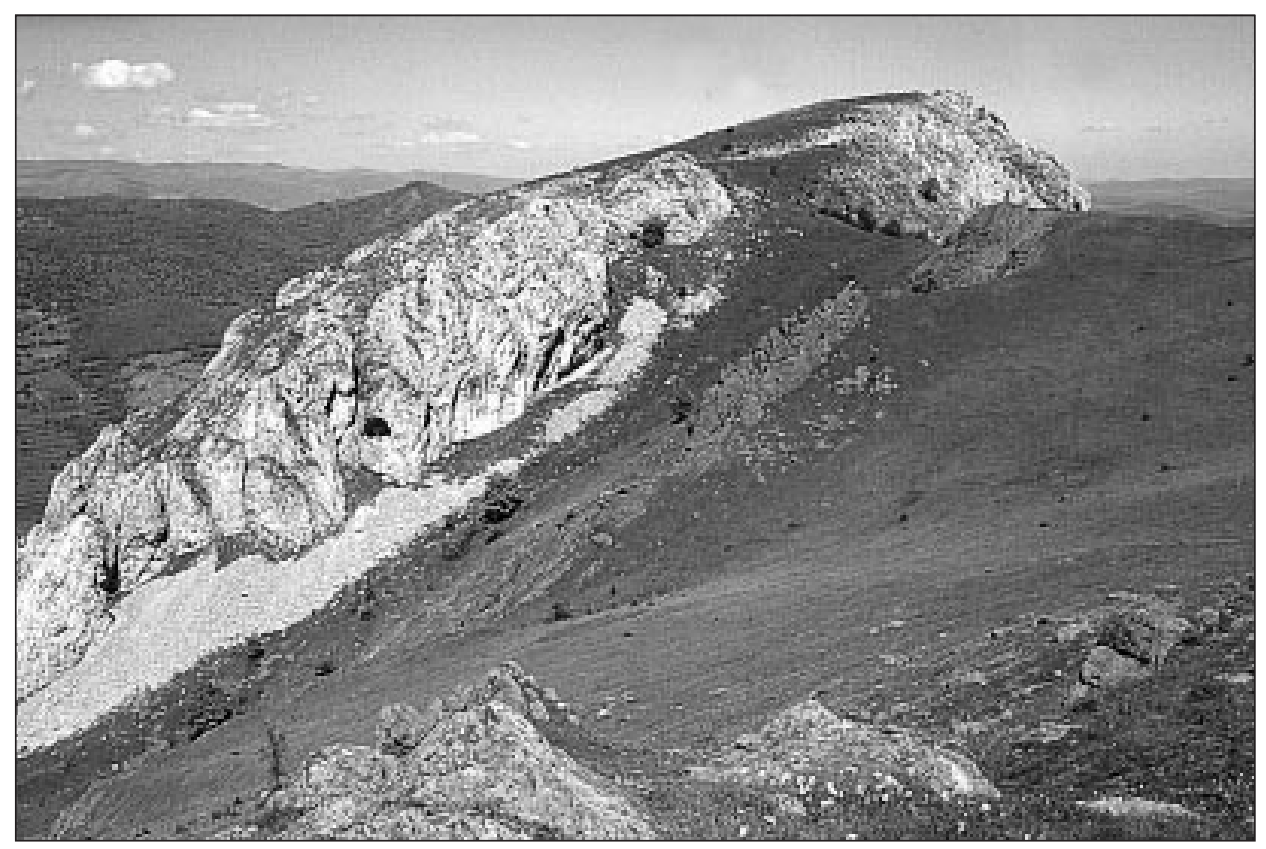

Photo 4: Patch reef (Mt. Secuiului; Székely-kö) in the Trascău Mountains. 
According to precipitation, with longer or shorter intervals, it produces violent eruptions, sometimes accompanied by sound effects as well. During May 1999 these eruptions were repeated every 10 minutes.

Titonic limestone nappes carry the highest peaks of the Trăscăului Mts. (Vrf. Ciumerna 1316 m, Vrf. Trăscăului 1217 m and Bedeleu plateau 1282 m). Varied karstic forms developed on the bigger limestone nappes of the Mts. Dolines, swallow holes are virtually present only here in the territory of the Mts. The number of dolines is unusually great at the Bedeleu peak, where in a narrow belt the rocks of the one-time volcanic range surface, and the waters flowing down disappear in lines of swallow holes on both sides. There are no permanent waterflows on the limestone plateaus of the Mts, the majority of precipitation infiltrates, thus increasing the waters of underground streams, which continue their journey in giant underground cave systems until they issue as karst springs at the edge of the Mts. The Huda lui Papară cave [Szolcsvai-barlang] has been known for a long time, where the underground stream flowing from the Ponor basin flows through its $2 \mathrm{~km}$ long wide corridors, breaking through a horseshoe-shaped extension of the Bedeleu Mts. The Huda lui Papară cave is one of the most interesting karst phenomena of the Transylvanian Middle Mts. due to its picturesque swallow hole (Vînată), and its giant mouth opening with waterfalls at the outflow of the underground stream (Photo 1).

\section{Smaller-sized klippes}

These are a frequent karst type on the southern part of the Transylvanian Middle Mts. The highest peaks of the Transylvanian Ore Mts. rise from the few $100 \mathrm{~m}$ high levelled surfaces of the ophiolits and flysh deposits, and are made up of a harder Jurassic limestone (or are remains of eruption centres of Tertiary volcanoes). The Vîlcan $(1257 \mathrm{~m})$, the most beautiful klippe of the Ore Mts (Photo 2). rises as a rocky, wild cliff from the surrounding rounded, gentle sloping sandstone backs (Fig. 7). Its peak is strongly karstified, covered by dolines and karren fields, while at its edges the limestone is broken up into towers. Klippes carrying karstic forms are found in the environment of Băița and Geoagiu Băi. The Pleşa Ardeului $(856 \mathrm{~m})$, the Pleşa Mare $(714 \mathrm{~m})$, as well as the Măgura Băiței $(673 \mathrm{~m})$ belong to this range. The waterflows running towards the Mureș break through the east-west range by beautiful, small passes (Cheia Ardeu, Ch. Bșiței). The Piatra Cetii [Csáklya-kő] (1233 m) and Vrf. Pleşii (1250 m) belong to a smaller klippe in the Trăscăului Mts (Fig. 8).

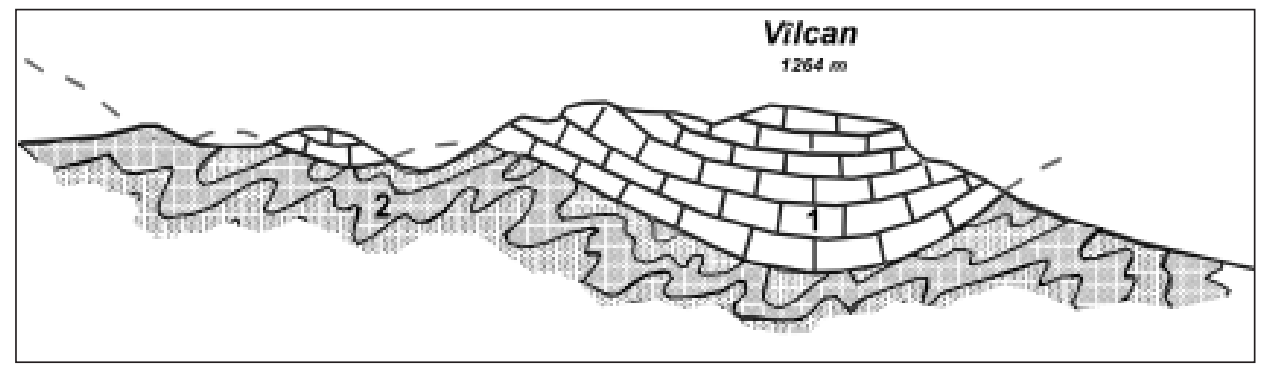

Fig. 7: Cross section of the Mt. Vîlcan (Transylvanian Ore Mts.-MetaliferiMts.) (after M. Ilie). Legend: 1. Jurassic limestone, 2. Upper Cretaceous and Paleogene flis. 


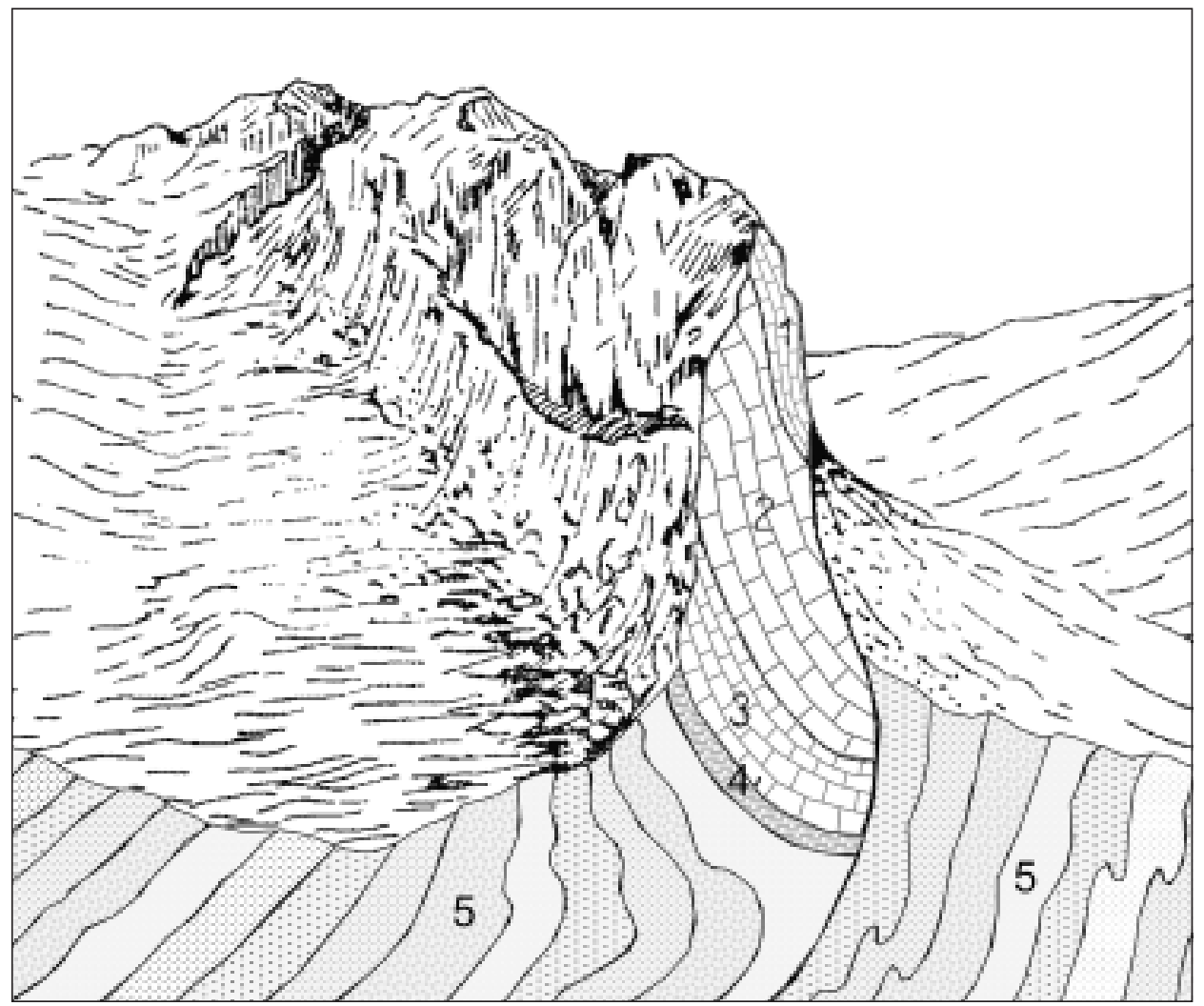

Fig. 8: Cross section of the Vârful Plesii Trascău (Torockói) Mountains Smaller sized klippe (after S. Bordea).

Legend: 1. Jurassic Saccocoma limestone (Kimmeridgian), 2. Tithonian limestone, 3. Limestone (Berriasian), 4. Marls (Hauterivian), 5. Flis.

\section{Olistolits}

Karst developing on olistolits is only found at the southern part of the Transylvanian Middle Mts., in the Transylvanian Ore Mts. and the Trăscăului Mts. The formation of this karst type is connected to the specific evolution history of the two mountains.

At the end of the Jurassic period, in the basin of the "Mureş ocean", on the volcanic backs reaching sea level, a large quantity of reef limestone developed. From the Lower Jurassic a huge mass of sediment rushed down as turbidite on the continental slopes and was deposited as flysh at the bottom of the geosynclinal. Huge Titonic limestone, basalt and granite blocks were embedded into the sand-clay-marge deposits, which slipped into the material of the flysh already as solid rock blocks. The smaller in size is referred to as the olistolits, while the larger, the olistotrimms. The whole deposit was accumulated as flysh. The flysh was formed mainly in the Upper Creta- 


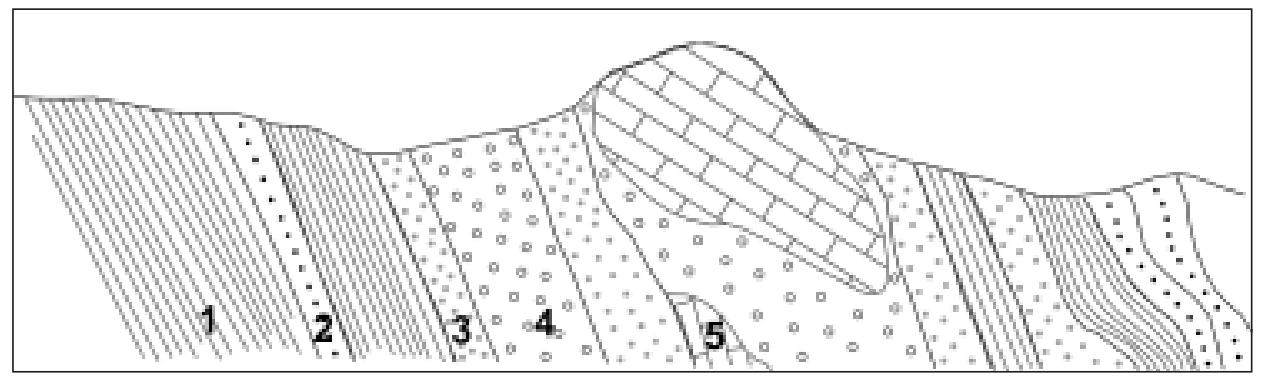

Fig. 9: Cross section of the Mt. Sfredelaşul (olistolit) (after M. Bleahu).

1. Greyish-black slates, 2. Yellow micaceous sand, 3. Microconglomerate, 4. Limey conglomerate, 5. Upper Jurassic (Titon) limestone olistolit.

ceous, when the fold and nappe development, and a quick uprisal connected to the closing up of the "Mureş ocean" resulted in a large quantity of sediment (Ianovici et al. 1969). The olistolits embedded in flysh are the most interesting parts of the southern Transylvanian Middle Mts.

Limestone plays a very important role in the formation of landscape in the territory of the Trăscăului Mts. The most striking surface forms of the range are connected to the Titonic "Stramberg" limestone of the Jurassic, and occur in the most varied structural forms (nappe, klippe, olistolits). Besides the smaller and larger klippes (Piatra Cetii $1233 \mathrm{~m}$ and the Vrf. Pleşii $1250 \mathrm{~m}$ ) hundreds of limestone blocks (olistolits) rise from the embedded Cretaceous flysh surface, appearing as solitary reefs or in groups, forming imposing peaks on the south-eastern edge of the Mts. (P. Craivei 1082 m, P. Bulzului 939 m, Prisaca $1150 \mathrm{~m}$ and Sfredelaşul $1132 \mathrm{~m}$ ) (Fig. 9) (Photo 3).

\section{Patch reefs}

The limestone plateau between Turda [Torda] and Tureni [Túr] is built up partly from Upper Jurassic Stramberg limestone and from Urgon limestone settling on the basalt blocks of underwater volcanic backs. This plateau encloses the most imposing gorge of the Carpathians, the Cheila Turda [Tordai-hasadék] gorge. The mountains bordering the Trascău [Torockói] basin belong to this type (Piatra Secuiului [Székely-kő] 1128 m, Pleşa 836 m, Data 898 m, Răchiş 775 m) (Photo 4).

\section{Tertiary basin sediment (Eocene limestones)}

The characteristic Upper Eocene aged limestone, dolomite and marl layers at the edge of the Transylvanian basin surface on the eastern edge of the Meseş Mts., and in a 2-3 km broad band follow the mountain range (Fig. 10). On the peaks and slopes around $500 \mathrm{~m}$ the karstic surface forms appear sporadically. The Eocene basin sediment karst appears especially spectacularly northeast of the Meseş Mts, on the Purcareț-Mesteacăn plateau, which is included by most geographers in the Transylvanian basin. 


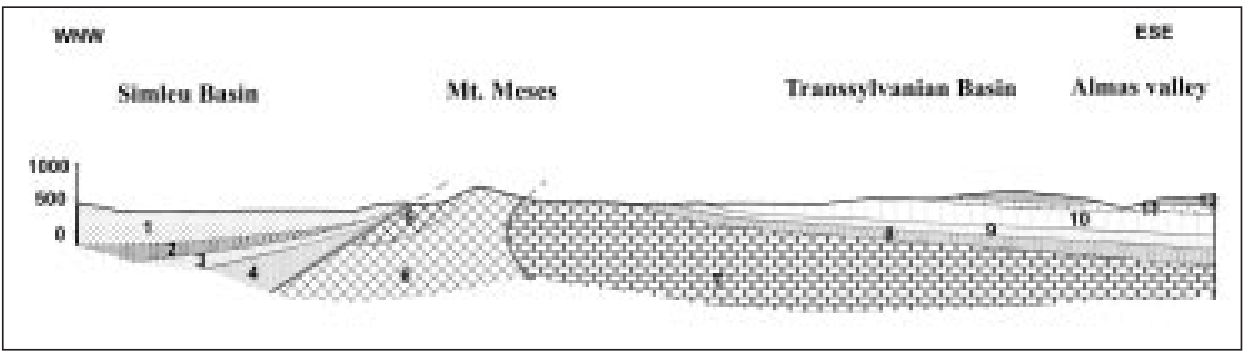

Fig. 10: Cross section of the Mt. Meses (after the 1:200 000 geological map of Romania, 10. Cluj).

Legend: 1. Pannon sediments, 2. Sarmatian sediments, 3. Badenian sediments, 4. Carpathian sediments, 5. Upper Proterozoic sericite-chlorite schists, 6. Mica schists and paragneis (Upper pcm.), 7. Nummulitic limestone and Eocen margel, 8-9-10. Oligocen sediments, 11. Lower Miocen sediments.

\section{TYPES OF KARST RELIEF}

\section{Mountain karst}

The greater part of the Transylvanian Middle Mts belongs to the mountain karst category and is found between 500-600 - 1300-1400 m above sea level.

\section{Plateau karst}

Those karst plateaus belong here where the temperate zone karstic surface forms appear entirely (Ponoru Negreni, Padis, Vaşcău karst and karst plateaus of the Padurea Craiului and Trăscăului mountains). The different sized and formed dolines sometimes occur in hundreds and thousands, while the most optimal conditions are marked by swallow holes with temporary or permanent water supply, karstic basins, karren fields, underground streams, shafts and caves.

\section{Dissected karst of horst and combined fold-fault structures}

There is also an abundance of surface and under surface karstic forms on dissected karst of horst and combined fold-fault types of karsts. The most striking feature is that the bigger, continuous karst plateaus are missing, the tectonisation and erosion is greater.

The smaller karsts on the west and north edge of the Bihar Mts. can be listed in this type, as well as the karstic blocks of the so-called Someş ditch on the territory of the Vlădeasa Mts. The western edge of the Bihar Mts. is built up of the rocks of the Codru nappe, where the carbonated rocks occur only in patches (in the environment of Crişul Băița, Fericel and Sighiştel). The complicated geological construction of the territory and the strong tectonisation (limestone, dolomite, crystalline slate, conglomerate, banatit magmatites) resulted in the mosaic-like arrangement of the rocks, which is reflected in the relief and hydrography (Ianovici et al. 1976). 
The karst developing on the western edge of the Bihar Mts., and the karst of the spring region of the Someşul Cald is not plateau-like in form due to a great extent of tectonisation. The surface dissection is big, the waterflows cut deep gorges into the limestone blocks embedded in nonkarstified rocks. The karst incorporating the Sighiştel [Szegyesdi] valley is prominent because of its great number of caves. In the $8 \mathrm{~km}$ long gorge 26 caves are known, most of them important morphologically or speleologically. The first cave of historical Hungary to be described (Peşteră de la Fînațe) [Szénaverősi, vagy Fonácai-cseppkőbarlang] opens in the Bulz valley, running parallel with the Sighiştel valley. This $270 \mathrm{~m}$ long, wide spring cave was introduced by Sándor Nedeczky in 1774 in Latin.

The karst of the Crişul Băița spring region is recorded as an independent karst region, which runs along the serpentine road between Băița and the Arieș valley. The most interesting sights are hidden in the deep valley of Criş - one of the greatest natural treasures of the Bihar Mts., the Porțile Bihorului [Bihar-kapu], which is the giant mouth of a spring cave together with a collapsed doline. In its entrance hall the outflowing water cascades down in a waterfall.

In the small karst region along the Crăiasa stream a few years ago a small cave system was explored due to stone mining. The cave obtained its name from the bear skeleton found here (Peşteră Ursurilor). The snow white dripstones of the Peşteră Ursurilor cave attract a large number of visitors, and this is also the only cave in the Transylvanian Middle Mts. with electric lights.

The karst of the Someşul Cald is connected to the north-east edge of the Padis plateau, which developed mainly on Lower Cretaceous limestone. The waterflows rushing down the southern slopes of the Vlădeasa [Kalota-havas] mountain range (Someşul Cald, Alunu Mic and Mare, Ponor) break through the average 1300-1400 m high karst plateau with a deep gorge, and in their valleys collect the infiltrating waters from the higher peaks. The exceptionally beautiful gorge was cut through by the Someşul Cald. The valley section, hiding ruined caves, abysses, karst springs, canyons, and swallow holes, is one of the most interesting landscape in the Bihar Mts. One of the spring branches of the Someșul Cald flows through the Peșt. Rădesei [Aragyásza] cave, whose ceiling was torn up in a number of places, while its lower end is totally open. The formation of valleys with the breaking up of the cave's ceiling can be best studied here in the whole of the Carpathians. Another famous sight in the karst region is the Peșt. Onceasa [OncsászaiCsont-barlang], which is referred to by the shepherds as Dragon Cave (Peșt. Zmeilor), because of the accumulated ancient mammal bones. The cave is a well-known archaeological and palaeontological site with a great amount of bone deposits of the now extinct cave bear.

\section{Karst of klippen structure}

This karst developed on the klippe and olistolits of the Transylvanian Ore Mts. and the Trascăuli Mts. (see above) The plateau-like levelled surface of the bigger klippes was strongly karstified, on their planinas covered by dolines and karren fields, swallow holes, shafts and caves are present. At the top of the smaller olistolits flat tops are rare and so dolines are lacking. On their sharp, crest-like spines and rocky, barren slopes essentially only different type karren forms are found. Caves are rare here. 


\section{Karst of pediment plains and terraces}

This is not a very well spread karst type in the territory of the Transylvanian Middle Mts. A smaller karstic territory developed on the uplifted eastern edge of the Meseş Mts. on Eocene Nummulite limestone belongs to this group (Fig. 10). The horizontal layers of the Nummulite limestone frequent on the edge of the Transylvanian Basin were bent slightly with the uplift of the Meseş Mts. and rose on the territory of the eastern slope. On the surface of the well soluble limestone karstic forms developed sporadically.

\section{Basin karst}

Mostly karsts formed on Eocene Nummulite limestone belong to this group. In reality it is a general karst type on the outskirts of the Transylvanian Middle Mts. in the strict sense, on the edge of the Transylvanian Basin (Kalotaszeg, Purcareț-Mesteacăn plateau, north-east margin of the Meseş Mts.). Here it deserves only mentioning, if we accept the regional arrangements of some of the authors, who list some parts of the hilly basin region concealing Tertiary karstic rocks in a broader sense to the Transylvanian Middle Mts.

\section{High mountain karst}

The Pietrele Alba karst region lies at the south-eastern foot of the Vrf. Vlădeasa (1837 m), built up of banatital magmatites. The folded and tectonisated blocks of the karstified Upper Jurassic Stramberg limestone are found in the so-called Someş ditch, but they surface in the sharp spine of the Pietrele Alba $(1557 \mathrm{~m}$ ) (Ianovici et al. 1976). The barren, sharp crest of the white stones is furrowed by different karen forms, and at its foot, in the Răchițele valley, and its upper continuation in the Seacă (Dry) valley, the most interesting karstic phenomena of the territory can be found. Well-developed swallow holes line up in the valley bottom, which transfer the waters of the stream into the depths. The best-known cave of the valley, the Vîrfuraş cave is 2,5 km long.

\section{MORPHOCLIMATIC KARST TYPES}

\section{Karst of the temperate zone}

The karsts of the Transylvanian Middle Mts., with one exception, are situated in middle mountainous heights, where karstification takes place in the Temperate Zone (moderately continental, moderately warm and moderately humid climate, annual precipitation total is $600-800 \mathrm{~mm}$ ). The amount of annual precipitation varies between wide limits in different regions of the mountain range; the least on the eastern territory neighbouring the Transylvanian basin $(600-800 \mathrm{~mm})$, the most on the western edge of the Bihar and Vlădeasa Mts $(1500-1700 \mathrm{~mm})$, where the air masses arriving from the west are forced to rise and their humidity is condensed. The main annual temperature is between 2 and $8^{\circ} \mathrm{C}$. The precipitation and temperature circumstances create optimal conditions for karstic corrosion, so where other conditions for karstification are given, the Temperate zone surface and sub-surface karstic forms developed in great variety. 


\section{High mountain climate karst}

This karst type is not general in the Transylvanian Middle Mts., its only high mountain climate karst is the $1557 \mathrm{~m}$ high, barren, cliff spine with karren slopes of the Pietrele Alba, where the climatic basis only slightly differs from the few hundred meter lower karsts. Precise climatic measurements and morphological studies were not conducted on its territory.

\section{CONCLUSION}

Karstified rocks occur in the Transylvanian Mountains over such a large area and in such a great variety that to show all is impossible in the scope of this paper. During my research I studied the karsts from morphogenetic, geological-structural and lithological aspects. There are karsts which are formed out of old crystalline limestone, and also from younger limestones from the Mesozoic and Tertciary. There are three levelled limestone surfaces (karstoplains) in the Transylvanian Mountains, which developed under different climatic conditions and age. According to karstic relief I identified mountain karsts, karst of pediment plains and terraces, basin karsts and high mountain karsts. I conducted research on the karst from the morphoclimatic point of view as well.

The classification of the karst regions of the Transylvanian Middle Mts. from different points of view (surface cover, the degree of exhumation, etc.) due to the absence of reliable data is difficult.

\section{REFERENCES}

Cocean, P. 1985: Les surfaces de nivellement karstique des monts Apuseni. Travaux de L'Institut de Spéologie „Émile Racovitza” 24. pp. 97-104.

Cociuba, I.-Silvestru, E. 1989: Hypothesis on a Genetical relation between the actual karst and the bauxite-bearing paleokarst at the Jurassic/Cretaceous boundary in the Piatra Craiului Mountains (Romania). Trav. Inst. Spéol. Émile Racovitza, t. 28., pp. 87-90.

Hevesi A. 1986: Hidegvizek létrehozta karsztok osztályozása. Földr. Ért. 35. 3-4. pp. 231-254.

Jakál, J. 1978: Morfoštruktúrna analỳza a jej využitie pri typologii krasu. Slovenskỳ kras 16. pp. 17-37.

Jakál, J. 1993: Karst geomorphology of Slovakia (Typology). Geographia Slovaca 4. Geogr. Ústav Bratislava, pp. 1-38.

Jakucs L. 1971: A karsztok morfogenetikája. Akadémiai kiadó, Budapest, 310 p.

Jakucs L. 1977: A magyarországi karsztok fejlődéstörténeti típusai. Karszt és Barlang 1-2 pp. 1-16.

Ianovici, V. \& Giuscă, D. \& Ghițulescu, T. P. \& Borcoş, M. \& Lupu, M. \& Savu, H. 1969: Evolutia geologică a Muntilor Metaliferi. Acad. R.S.R. București, p. 741.

Ianovici, V. \& Borcoş, M. \& Patrulius, D. \& Lupu, M. \& Dimitrescu, R. \& Savu, H. 1976: Geologie Munților Apuşeni. Acad. R.S.R. Bucureşti, p. 631.

Móga J. 1995: Az Erdélyi-középhegység (Muntii Apuşeni). Földr. Közl. 119. 2. pp. 105-136. 
Orâşeanu, J. 1985: Considerations on the hydrogeology of Vaşcău plateau (Codru Moma mountains). Theoretical and applied karstology, 2. pp. 199-209.

Orâşeanu, J. \& Gaşpar, E. \& Pop, I. \& Tănase, T. 1991: Tracer experiments in the karst area of Bihor mountains (Romania). Theoretical and applied karstology, 4. pp. 159-172.

Pop, Gh. 1962: Istoria morfogenetică a vecchii suprafețe eroziune Fărcasa din Munții Gilăului (M. Apuşeni). SUBB-GG, VII.

Rusu, T. 1988: Carstul din Pădureá Craiului. Edit. Dacia Cluj-Napoca, p. 254.

Tulogdi J. 1972: A Berettyó forrásvidékének karsztjelenségei. Karszt és Barlang I-II. pp. 1-4.

Veress M. 1992: Karsztmorfológiai sajátosságok a Pádis fedett karsztjának példáján. Földr. Közl. 116. 3-4. pp. 125-141.

Geogrăfia Romăniei III. Carpații şi Depresiunea Transilvaniei. Inst. De Geogr. Bucureşti, Edit. Academiei, 1987. P. 656.

The 1:50 000 and 1:200 000 geological maps of Romania

\section{MORFOGENETSKI TIPI KRASA V TRANSILVANSKEM GOROVJU (APUSENI)}

\section{Povzetek}

V Transilvanskem gorovju zakrasele kamnine prekrivajo tako obsežno ozemlje in so tako različne, da vseh ni mogoče prikazati v okviru tega prispevka. Ta kras sem preučeval z morfogenetskega, geološko-strukturnega in litološkega vidika. Tako imamo kras, ki se je razvil v starih kristalinskih apnencih, pa tudi takega v mlajših, mezozojskih in terciarnih apnencih. V Transilvanskem gorovju so tri uravnave na apnencih (»karstoplain«), nastale v različnih klimatskih okoljih in v različnem času. Glede na kraški relief ločim gorski kras, kras pedimentnih ravnin in teras, kras v kotlinah in visokogorski kras. Kras sem preučeval tudi z morfoklimatskega vidika.

Klasifikacija kraških ozemelj v srednjem Transilvanskem gorovju, temelječa na različnih vidikih (površinski pokrov, stopnja ekshumacije, itd.), je zaradi pomanjkanja zanesljivih podatkov težka. 